\title{
Przemiany funkcjonowania Zakładów Przemysłu Dziewiarskiego „Jarlan” S.A. w Jarosławiu (ze szczególnym uwzględnieniem lat 1999-2003)
}

Postępujący proces globalnego rozwoju społecznego, gospodarczego i kulturowego stawia nowe wyzwania cywilizacyjne i tworzy odmienne niż dotychczas uwarunkowania przemian zarówno dla całego świata, poszczególnych kontynentów, państw, a także dla różnej skali układów przestrzennych [Zioło 1999]. W tych zmieniających się warunkach przechodzenia z gospodarki centralnie sterowanej do gospodarki rynkowej, w obliczu których stanęła Polska, bardzo ważnym problemem jest zachowanie się podstawowego elementu struktury gospodarczej, jakim jest przedsiębiorstwo przemysłowe.

W świetle przedstawionych założeń w niniejszym artykule podjęta zostanie analiza wybranych zagadnień funkcjonowania i przekształceń Zakładów Przemysłu Dziewiarskiego „Jarlan” S.A. w procesie przemian systemu gospodarowania. W artykule zmierzano do określenia tendencji zmian funkcjonowania analizowanego przedsiębiorstwa przemysłowego w latach wprowadzania reguł gospodarki rynkowej. Szczególnie zwrócono uwagę na zmiany dokonujące się w przedsiębiorstwie w latach 1999-2003.

Zakłady Przemysłu Dziewiarskiego „Jarlan” S.A. w Jarosławiu powstawały w kilku etapach. 30 lipca 1965 roku Komisja Planowania przy Radzie Ministrów podjęła decyzję dotyczącą budowy zakładu przemysłu dziewiarskiego w Jarosławiu. Czynnikami, które w głównej mierze przyczyniły się do lokalizacji tego przedsiębiorstwa w Jarosławiu były:

a) potrzeba uprzemysłowienia miasta i regionu,

b) wolne zasoby siły roboczej - zwłaszcza kobiet,

c) dogodne położenie Jarosławia na trasie komunikacyjnej Kraków-Przemyśl i dalej na wschód,

d) duży rynek zbytu.

Pierwszy z wymienionych czynników spełniał warunki jednej z socjalistycznych teorii lokalizacji, a mianowicie „Aktywizacji obszarów zacofanych gospodarczo”, do których bez wątpienia należał obszar Jarosławia. Jak wynika z założeń, uruchomienie tego zakładu miało przyczynić się do rozwoju gospodarczego regionu poprzez wykorzystanie istniejących tutaj rezerw siły roboczej, zwłaszcza kobiet. Większe zakłady na tym terenie: Huta Szkła, Zakłady Mięsne czy Zakłady Przemysłu Zbożowego dawały zatrudnienie głównie mężczyznom. Jedynie Zakłady Przemysłu Cukierniczego „San” zatrudniały w tym regionie więcej kobiet, lecz i tak nie w pełni wykorzystywały istniejące rezerwy siły roboczej tej płci. Jak przyjmuje Winiarski [1961] występowanie niewykorzystanych nadwyżek siły roboczej prowadzi do 
utajonego bezrobocia, zwłaszcza na wsi. Uruchomienie dużego zakładu zatrudniającego kobiety spowodowało w pewnym stopniu wchłonięcie nadwyżek siły roboczej kobiet nie tylko z Jarosławia, ale i z przyległych miejscowości. Istotnym czynnikiem lokalizacji zakładów przemysłowych była również dostępność komunikacyjna. Ten czynnik miał duże znaczenie przy lokalizowaniu Zakładów Przemysłu Dziewiarskiego, gdyż usytuowano je przy międzynarodowej drodze kołowej E4 między Rzeszowem a Przemyślem i linii kolejowej wiodącej z zachodu na wschód. O lokalizacji szczegółowej zakładu w południowo-wschodniej części Jarosławia zadecydowały:

- dogodne położenie geologiczne i odpowiednie ukształtowanie terenu,

- pokrycie słabymi glebami,

- możliwość łatwego i taniego doprowadzenia dróg kołowych,

- możliwość pobierania wody z Sanu,

- możliwość wykonania niezbędnych działań z zakresu: kanalizacji, wodociąó́w i oczyszczalni, co przyniosło korzyść zarówno miastu, jak i zakładowi.

Ukształtowanie terenu, na którym umiejscowiono zakład jest korzystne, ponieważ jest to płaska powierzchnia o wysokości $250 \mathrm{~m}$ n.p.m., w wyniku czego wystąpiły znaczne oszczędności związane z niwelacją tego obszaru [Baran 1994]. ZPDz „Jarlan” S.A. są przykładem planowej polityki równomiernego rozmieszczenia zakładów przemysłowych na terenie całego kraju realizowanej przez państwo w latach gospodarki centralnie sterowanej.

Kolejny etap kształtowania się ZPDz „Jarlan” S.A. miał miejsce 30 lipca 1968 roku, kiedy Ministerstwo Przemysłu Lekkiego powołało do życia przedsiębiorstwo pod nazwą Zakłady Przemysłu Dziewiarskiego „Jarlan”. W dniu 12 marca 1971 roku z maszyny kotonowej zszedł pierwszy wyrób - bluzka damska z japońskiej anilany. W trakcie oddawania przez zakład budowlany poszczególnych obiektów, instalowano w nich park maszynowy oraz w szybkim tempie szkolono załogę. Następne lata charakteryzowała intensywna rozbudowa zakładu. 30 września 1972 roku zakończono budowę przedsiębiorstwa, a 1 października oddano go do eksploatacji. W 1972 roku w skład struktury Zakładów Przemysłu Dziewiarskiego „Jarlan” w Jarosławiu wchodziły 4 zakłady: macierzysty przy ul. 3 Maja, zakład „A” przy ul. Poniatowskiego oraz zakład „C” w Sieteszy gmina Kańczuga - produkcja bawełniana, i zakład „B” w Przeworsku - produkcja dziewiarska. W 1990 roku zlikwidowano zakład w Sieteszy, a w 1991 roku zakład „A” w Jarosławiu. Brak surowca spowodował zamknięcie tych zakładów, gdyż do 1989 roku bawełnę sprowadzano z Brazylii, Egiptu i Turcji (za pośrednictwem firmy Textlimpex), zaś po 1989 roku produkcję opierano wyłącznie na bawełnie sprowadzanej z Brazylii.

2 marca 1992 roku „Jarlan” stał się jednoosobową spółką Skarbu Państwa i od tej chwili przyjął nazwę Zakłady Przemysłu Dziewiarskiego „Jarlan” S.A. w Jarosławiu. Spółka działała na podstawie kodeksu handlowego z 1990 roku o prywatyzacji przedsiębiorstw. Wszystkie akcje przedsiębiorstwa należały wówczas do Skarbu Państwa [Baran 1994]. Następnym etapem zmierzającym do prywatyzacji ZPDz „Jarlan” S.A. było włączenie spółki do programu Powszechnej Prywatyzacji. 12 grudnia 1995 roku akcje przedsiębiorstwa zostały wniesione do Narodowych Funduszy Inwestycyjnych (http://starostwo.jaroslaw.pl). W 1995 roku 33\% akcji ZPDz „Jarlan” S.A. znalazło się pod kontrolą Narodowego Funduszu Inwestycyjnego „Piast”, a kolejne 33\% w równych częściach zostało podzielone pomiędzy pozostałych 15 funduszy, tworzących z „Piastem” Narodowy Fundusz Inwestycyjny. NFI „Piast” lansował projekt utworzenia holdingu wokół łódzkiej firmy odzieżowej „Próchnik”. Ponadto posiadał udziały wielu firm w branży odzieżowo-dziewiarskiej, które powiązane przez „Próchnik” miały tworzyć zespół spółek. W tym celu „Próchnik” przeprowadził emisję akcji, wyce- 
nionych na $140 \mathrm{mln}$ złotych. ZPDz „Jarlan” S.A. były w trzech czwartych własnością „Próchnika” i w jednej czwartej własnością państwa [Witczak 2004]. W ciagu kilku lat, ze względu na złą sytuację ekonomiczną, „Próchnik” rozpoczął sprzedaż swoich spółek zależnych. W 2000 roku banki wypowiedziały „Próchnikowi” kredytowanie, w tej sytuacji holding został rozwiązany. Wówczas prezesem i dyrektorem generalnym Zakładów Przemysłu Dziewiarskiego „Jarlan” S.A. został Krzysztof Dajczak, który w październiku 2002 roku kupił 75\% akcji przedsiębiorstwa. Pozostałych 25\% udziałów należało wciąż do Skarbu Państwa, a ten wystawił je na sprzedaż [Delmanowicz 2002]. Komisja Zakładowa, posiadająca osobowość prawną, zainwestowała swoje fundusze i zakupiła akcje Skarbu Państwa oraz część od K. Dajczaka. W ten sposób 44\% akcji przedsiębiorstwa należy do Komisji Zakładowej Solidarność, a pozostała część do prezesa ZPDz „Jarlan” S.A. [Witczak 2004].

\section{PRZEMIANY STRUKTURY ZALOGI}

W badaniach zakładów przemysłowych szczególnie dużo uwagi poświęca się problemom zatrudnienia, które warunkuje prawidłowe funkcjonowanie firmy. Przedmiotem niniejszej analizy będzie wielkość i dynamika zatrudnienia oraz struktura płci pracowników Zakładów Przedsiębiorstwa Dziewiarskiego „Jarlan” S.A. Jak zauważył B. Kortus [1986], załoga każdego zakładu przemysłowego stanowi zawsze cząstkę społeczeństwa, dlatego dokonujące się w danej społeczności przemiany, na przykład polityczne czy gospodarcze, rzutują na postawy i motywację działań zatrudnionych. Z powyższych przesłanek wynika fakt, że przy badaniu zatrudnienia należy wziąć pod uwagę elementy otoczenia, czyli uwarunkowania zewnętrzne, gdyż wpływają one w istotny sposób na prawidłowe funkcjonowanie danego zakładu przemysłowego w przestrzeni.

\section{Zmiany w poziomie zatrudnienia}

Dynamikę zatrudnienia przedstawiono w latach 1980-2003, by w ten sposób pokazać zmieniający się potencjał produkcyjny przedsiębiorstwa (tab. 1).

Tabela 1. Dynamika zatrudnienia w Zakładach Przemysłu Dziewiarskiego „Jarlan” S.A. w latach 1980-2003 (w \%)

\begin{tabular}{|l|c|c|}
\hline \multicolumn{1}{|c|}{ Lata } & Liczba zatrudnionych & Dynamika zatrudnienia \\
\hline 1980 & 3468 & 100 \\
\hline 1985 & 3363 & 97 \\
\hline 1990 & 2837 & 82 \\
\hline 1995 & 2765 & 80 \\
\hline 1996 & 2497 & 72 \\
\hline 1997 & 2178 & 63 \\
\hline 1998 & 1541 & 44 \\
\hline 1999 & 1128 & 33 \\
\hline 2000 & 979 & 28 \\
\hline 2001 & 981 & 28 \\
\hline 2002 & 982 & 28 \\
\hline I poł. 2003 & 982 & 28 \\
\hline
\end{tabular}

Źródło: Opracowanie własne na podstawie danych uzyskanych z ZPDz „Jarlan” S.A. 
Rozpatrując dynamikę zatrudnienia w badanym przedsiębiorstwie należy zauważyć, że od 1980, czyli od roku, kiedy było najwyższe zatrudnienie, istnieje tendencja spadku tego wskaźnika. W roku rozpoczęcia produkcji, czyli 1 października 1972, załoga firmy liczyła 2066 pracowników. W ciagu 10 lat, w stosunku do 1980 roku, w ZPDz „Jarlan” S.A. liczba pracowników zmniejszyła się o 18\%, czyli o 631 osób. Zmniejszenie się liczby pracowników w analizowanym okresie było wywołane zamknięciem w 1990 roku zakładu „C” w Sieteszy, a rok później zakładu „A” w Jarosławiu. Największe zmiany w zatrudnieniu nastąpiły w latach 1990-1998. W tym okresie zwolniono 1296 osób. W 1995 roku Zakłady Przemysłu Dziewiarskiego w Jarosławiu zostały włączone do Powszechnego Programu Prywatyzacji. Gwałtownie pogarszająca się sytuacja finansowa w kolejnych kilku latach wynikała z tego, że ZPDz „Jarlan” S.A. związały się z firmą odzieżową „Próchnik” [Witczak 2004]. Miało to swoje odzwierciedlenie w poziomie zatrudnienia. W 1997 roku w jarosławskich zakładach dziewiarskich pracowało 2178 osób. To jedynie 63\% pracowników w porównaniu z rokiem 1980. Niestety proces przechodzenia z centralnego systemu planowania do gospodarki rynkowej, dla wielu pracowników „Jarlanu”, oznaczał utratę stanowiska pracy. W 2001 roku w przedsiębiorstwie zatrudnionych było 981 osób i ten stan zatrudnienia utrzymał się przez kolejne dwa lata. Od 29 września 2003 roku rozpoczęto zwolnienia grupowe w ramach ustawy z dnia 30 sierpnia 2002 roku „O restrukturyzacji niektórych należności publicznoprawnych od przedsiębiorców”* [Witczak 2004].

W związku z tym, że ZPDz ,Jarlan” S.A. zmniejszyły swą produkcję, posiadają wiele wolnych pomieszczeń, którymi od niedawna zaczęły się interesować rożnego rodzaju przedsiębiorstwa. Jedno z nich to amerykański Concern Lear Corporation. Planuje on rozpocząć w budynkach Zakładów Przemysłu Dziewiarskiego „Jarlan” S.A. w Jarosławiu produkcję części wyposażenia wnętrz samochodów, poszycia i tapicerki samochodowej. Docelowo kontrahent zamierza zatrudnić około 500 osób, by móc prowadzić działalność. ZPDz w Jarosławiu wygrały rywalizację o nowego inwestora z innymi lokalizacjami, na przykład na Litwie czy w Turcji oraz innymi miastami Polski [„Gazeta Jarosławska” 2004]. Zainteresowanie się przez amerykański koncern Jarosławiem daje szansę zaktywizowania rynku pracy w regionie oraz stanowi pozytywny sygnał dla innych przedsiębiorstw.

\section{Struktura płci załogi}

Podejmując analizę struktury płci pracowników ZPDz „Jarlan” S.A. nie trudno się domyśleć, że będą przeważały liczebnie kobiety, gdyż generalnie ze względu na predyspozycje fizyczne są bardziej poszukiwanymi pracownikami w tej branży. Stąd w strukturze zatrudnienia jest prawie 3,5 razy więcej kobiet niż mężczyzn, co było widoczne zarówno w 1980 roku, jak i obecnie (ryc. 1). Zjawisko to wynika również z faktu, iż wśród kobiet istnieją znacznie większe rezerwy siły roboczej na badanym obszarze. Duża część kobiet, które widniały w ewidencjach zatrudnienia, faktycznie nie wykonywała pracy, gdyż znajdowały się na urlopach wychowawczych. Przykładem może być sytuacja z 2000 roku, kiedy to zatrudnionych było 979 osób, lecz 612 osób przebywało na urlopach bezpłatnych i wychowawczych. Taka sytuacja wywołana jest przede wszystkim brakiem zamówień w niektórych okresach w ciągu roku. Wtedy to część osób kierowanych jest na bezpłatne urlopy. 


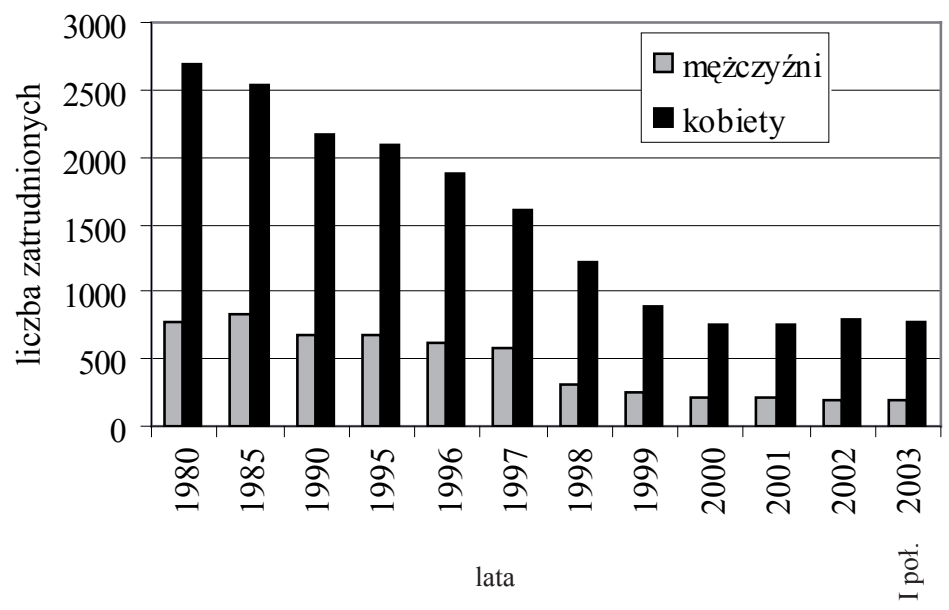

Ryc. 1. Zatrudnienie kobiet i mężczyzn w ZPDz „Jarlan” S.A. w latach 1980-2003

Źródło: Opracowanie własne na podstawie danych uzyskanych w ZPDz „Jarlan” S.A.

Najwyższy poziom zatrudnienia osób obu płci w ZPDz „Jarlan” S.A. był w 1980 roku i wynosił 781 mężczyzn oraz 2687 kobiet. Od tego roku przez cały okres objęty badaniami liczba zatrudnionych i kobiet i mężczyzn systematycznie się zmniejszała do 2000 roku, kiedy to zatrudnienie było na poziomie około 760-790 kobiet i około 200 mężczyzn. W takiej postaci poziom zatrudnienia utrzymał się przez 3 lata. W pierwszej połowie 2003 roku zatrudnionych było w jarosławskim zakładzie dziewiarskim 783 kobiety, to jest 30\% liczby zatrudnionych kobiet w porównaniu z rokiem 1980, oraz 199 mężczyzn, czyli po dwudziestu latach zatrudnienie mężczyzn zmniejszyło się o $72 \%$.

\section{ZMIANY POTENCJALU PRODUKCYJNEGO}

\section{ZaKŁadów PrZemystu DZiewiarskiego „Jarlan” S.A.} W ŚWIETLE WYBRANYCH MIERNIKÓW

Zagadnienie potencjału produkcyjnego było przedmiotem uwagi wielu autorów. Z. Zioło [1973] jest zdania, iż przy wydzielaniu form koncentracji przemysłu należy posługiwać się miernikami obrazującymi potencjał w różnych aspektach. Autor przy badaniach potencjału produkcyjnego przemysłu w województwie rzeszowskim posłużył się takimi miernikami, jak: wartość środków trwałych, liczba zatrudnionych, zużycie energii elektrycznej i moc zainstalowanych urządzeń odbiorczych. Zmierzając do określenia potencjału produkcyjnego ZPDz „Jarlan” S.A. zostaną uwzględnione następujące mierniki:
a) liczba zatrudnionych,
b) wartość środków trwałych,
c) wartość produkcji,
d) wartość zużytej energii elektrycznej. 
Dobór odpowiednich mierników jest trudny, a przyjęcie nieodpowiednich może doprowadzić do niewłaściwych wniosków. Zakładam, że przyjęte mierniki są na tyle trafne, że pomogą stworzyć pewnego rodzaju obraz przedsiębiorstwa.

Liczba zatrudnienia jest jednym z najczęściej używanych mierników w badaniach przedsiębiorstw, gdyż jest ona najłatwiej osiągalna. Kolejny miernik - wartość środków trwałych, przedstawia część majątku przedsiębiorstwa. Miernik ten zaliczany jest w sprawozdaniu finansowym ZPDz ,Jarlan” S.A. do rzeczowych aktywów trwałych. W skład środków trwałych wchodzą: grunty (w tym prawo użytkowania wieczystego gruntu), budynki, lokale i obiekty inżynierii lądowej i wodnej, urządzenia techniczne i maszyny, środki transportu oraz inne środki trwałe. Wartość produkcji to miernik obejmujący sumę cen produkowanych wyrobów wyrażanych w tysiącach złotych. Natomiast wartość zużytej energii określa stopień energochłonności danego przemysłu oraz jest jednym z kosztów produkcji, które oblicza się przy badaniach opłacalności produkowania danego wyrobu. W trakcie analizy potencjału produkcyjnego ZPDz „Jarlan” S.A. zostanie dokonane porównanie wybranych mierników za lata 1999 i 2002.

Tabela 2. Zmiany w potencjale produkcyjnym ZPDz „Jarlan” S.A. w latach 1999-2002

\begin{tabular}{|l|c|c|c|}
\hline \multicolumn{1}{|c|}{ Mierniki potencjału produkcyjnego } & 1999 & 2002 & $\begin{array}{c}\text { Dynamika wzrostu 2002 } \\
1999=100 \%\end{array}$ \\
\hline 1. Liczba zatrudnionych [w osobach] & 1128 & 982 & 87 \\
\hline 2. Wartość środków trwałych [w tys. zł] & 21083,9 & 18051,7 & 85 \\
\hline 3. Wartość produkcji [w tys. zł] & 54110,7 & 42268,5 & 78 \\
\hline 4. Wartość zużytej energii elektrycznej [w tys. zł] & $1157,0^{*}$ & 1078,9 & 93 \\
\hline
\end{tabular}

* dane za 2000 rok

Źródło: Obliczenia własne na podstawie danych otrzymanych od ZPDz „Jarlan” S.A.

W świetle przedstawionych mierników należy zauważyć generalny spadek ich wartości w badanym okresie. Największe zmiany zaszły w wartości produkcji, bo zmniejszyła się o $22 \%$, co stanowi spadek aż o 11 842,2 tys. złotych. Jest to związane ze zmniejszaniem się produkcji ze względu na brak zamówień. Podobne tendencje zmian zaznaczyły się w liczbie zatrudnionych oraz w wartości środków trwałych. W latach 1999-2002 liczba zatrudnienia zmniejszyła się o 146 osób, to jest o 13\%. Natomiast wartość środków trwałych zmniejszyła się o $15 \%$, co w wartości nominalnej wynosi 3032,2 tys. złotych. Najmniejsze zmiany nastąpiły w dynamice wartości zużytej energii elektrycznej, gdyż spadły o 7\%. Z powyższych przesłanek wynika, że wraz ze zmniejszaniem się rozmiaru produkcji nastąpił też spadek zużycia energii elektrycznej.

\section{ZAOPATRZENIE ZAKŁADU}

Zaopatrzenie zakładu w półprodukty to jedna z kwestii, od której zależy jakość wyrobu końcowego. Badanie tego zagadnienia jest bardzo trudne, ze względu na brak syntetycznych opracowań na ten temat. Analizując zaopatrzenie Zakładów Przemysłu Dziewiarskiego „Jarlan” S.A. należy podzielić całość zaopatrzenia na: surowce podstawowe, środki chemiczne i barwniki, dodatki dziewiarskie oraz opakowania. 
Surowce podstawowe, wykorzystywane przez jarosławskie przedsiębiorstwo dziewiarskie, to przede wszystkim: surowce roślinne - bawełna, surowce zwierzęce - wełna oraz włókna syntetyczne, np. włókna poliestrowe, włókna polikrylonitrowe. ZPDz „Jarlan” S.A. w Jarosławiu produkują ze wszystkich możliwych rodzajów przędz, na przykład z: acrylicu, angory, bawełny, jedwabiu, wiskozy, moheru, poliamidu, szetlandu, lambswoolu oraz ich mieszanek, w zależności od życzeń klienta. Czasami zdarzają się problemy w tej sferze, dotyczące przede wszystkim sytuacji pilnej potrzeby zakupu przędz niestandardowych (fantazyjne, melanżowe, mieszankowe - w zależności od życzenia klienta). Przedsiębiorstwo utrzymuje od kilkunastu lat kontakty z przędzalniami włoskimi, francuskimi, niemieckimi, hiszpańskimi i tureckimi. Dzięki tym porozumieniom, zakład posiada możliwości zakupu każdego rodzaju przędzy o dowolnym składzie. Istotną kwestią pozostaje cena i termin dostawy, lecz zawsze udaje się osiagnąć kompromis. Producenci przędz niejednokrotnie zmuszeni są do wprowadzenia zmiany technologii produkcji w celu sprostania wymaganiom ZPDz „Jarlan” S.A., które z kolei wynikają z oczekiwań klientów przedsiębiorstwa. Jakość środków chemicznych i barwników od lat utrzymuje się na bardzo wysokim poziomie. W celu zapewnienia wysokiej jakości swoich wyrobów analizowany zakład dokonuje zakupu przędz, środków chemicznych i barwników u producentów posiadających międzynarodowe normy i atesty, np. Eko-Tex, ISO. Dodatki dziewiarskie (wszywki, etykiety, guziki, nici, gumy) i opakowania (wkładki, kartony, worki, taśmy) dla „Jarlanu” dostarczane są przez polskich producentów, ponieważ są bardzo dobre jakościowo.

Badane przedsiębiorstwo ocenia sytuację zaopatrzeniową za ostatnie lata jako dobrą. Zakłady Przemysłu Dziewiarskiego „Jarlan” S.A. od wielu lat dokonują zakupów półfabrykatów od stałych i sprawdzonych dostawców. Jednakże w ostatnich latach ustawicznie poszukiwane są nowe źródła zakupów.

\section{WIELKOŚĆ I ASORTYMENT PRODUKCJI}

Zakłady Przemysłu Dziewiarskiego „Jarlan” S.A. posiadają szeroką ofertę wyrobów damskich, męskich i młodzieżowych. Produkowane są: golfy, półgolfy, kamizelki, bezrękawniki, tuniki, spódnice, spodnie. Wielkość produkcji jest wskaźnikiem znaczenia przedsiębiorstwa w regionie, kraju czy na świecie. Decyduje o jego pozycji na rynku. Produkcję można wyrazić w dwojaki sposób: wartościowo lub ilościowo.

Efektem działalności przedsiębiorstwa w latach 1999-2002 jest wzrost przychodu z tytułu sprzedaży wyrobów gotowych (tab. 3). W 2000 roku wystapił przychód w wysokości 40099 tys. złotych, a rok później już o prawie 3\% więcej. W 2002 roku ZPDz „Jarlan” S.A. za sprzedaż produktów przez nie wyprodukowanych odnotowały przychód ponad 43 mln złotych. Analizując produkcję wyrobów gotowych w sztukach zauważalne są wahania wywołane różnymi wielkościami zamówień w danym roku. Największą produkcję, sięgającą prawie 2,2 mln sztuk, przedsiębiorstwo zaznaczyło w 1999 roku. Natomiast najmniejsza, w badanym okresie, tylko rok później - w 2000 roku. Był to przełomowy dla firmy rok od momentu powstania. Spadek produkcji wywołany był zmianami własnościowymi zakładu. W 2001 roku ponownie wzrosła produkcja o $16 \%$ w stosunku do 2000 roku. Zmiany wynikające z restrukturyzacji zakładu odbijają się również w wielkości produkcji. W 2002 roku produkcja wyrobów gotowych zmniejszyła się o 84442 sztuki w stosunku do roku poprzedniego. 
Tabela 3. Wielkość i wartość wyrobów gotowych

w Zakładach Przemysłu Dziewiarskiego „Jarlan” S.A. w latach 1999-2002

\begin{tabular}{|l|c|c|}
\hline Rok & Produkcja wyrobów gotowych w sztukach & Wartość sprzedaży wyrobów gotowych w tys. zł \\
\hline \hline 1999 & 2190000 & $-*$ \\
\hline 2000 & 1515080 & 40099 \\
\hline 2001 & 1760917 & 41121 \\
\hline 2002 & 1676475 & 43338 \\
\hline
\end{tabular}

* brak danych

Źródło: Obliczenia własne na podstawie danych otrzymanych od ZPDz „Jarlan” S.A.

Dokonując analizy produkcji w ZPDz „Jarlan” S.A. należy podzielić cały asortyment produkcyjny na kilka grup:

- wyroby z maszyn kotonowych,

- wyroby z maszyn saneczkowych,

- wyroby z kooperacji - maszyny kotonowe,

- wyroby z kooperacji - maszyny saneczkowe.

Tabela 4. Produkcja w zakresie głównych produktów w ZPDz „Jarlan” S.A. w latach 1999-2002

\begin{tabular}{|l|r|r|r|r|r|r|r|}
\hline \multirow{2}{*}{ Asortyment } & \multicolumn{3}{|c|}{ Ilość w tys. sztuk w latach } & \multicolumn{2}{c|}{ Dynamika } \\
\cline { 2 - 7 } & 1999 & 2000 & 2001 & 2002 & $\begin{array}{r}1999-2000 \\
1999=100 \%\end{array}$ & $\begin{array}{r}\text { Dynamika } \\
2000-2001 \\
2000=100 \%\end{array}$ & $\begin{array}{r}\text { Dynamika } \\
2001-2002 \\
2001=100 \%\end{array}$ \\
\hline $\begin{array}{l}\text { Wyroby z maszyn } \\
\text { kotonowych }\end{array}$ & 1806,8 & 1420,0 & 1709,9 & 1562,7 & 78,6 & 120,4 & 91,4 \\
\hline $\begin{array}{l}\text { Wyroby z maszyn } \\
\text { saneczkowych }\end{array}$ & 78,0 & 41,5 & 23,7 & 74,4 & 53,2 & 57,1 & 313,9 \\
\hline $\begin{array}{l}\text { Wyroby z kooperacji } \\
\text { - maszyny kotonowe }\end{array}$ & 294,1 & 53,4 & 27,9 & 12,5 & 18,1 & 52,2 & 44,8 \\
\hline $\begin{array}{l}\text { Wyroby z kooperacji } \\
\text { - maszyny saneczkowe }\end{array}$ & 11,1 & 0,1 & 1,4 & 1,7 & 0,9 & 1400 & 121,4 \\
\hline RAZEM & 2190,0 & 1515,0 & 1760,9 & 1676,5 & 150,8 & 1629,7 & 571,5 \\
\hline
\end{tabular}

Źródło: Obliczenia własne na podstawie Sprawozdania z działalności Spółki za lata 2000-2002

Największa produkcja w każdej z grup nastąiła w 1999 roku (tab. 4). Zmniejszenie produkcji w 2000 roku w relacji z rokiem poprzednim, jest wynikiem decyzji podjętej przez Zarząd ZPDz „Jarlan” S.A. o zaniechaniu realizacji zamówień krajowych i eksportowych na sezon jesienno-zimowy. Ze względów finansowych przedsiębiorstwo nie wprowadziło zmian w asortymencie produkcji oraz nie uruchomiło znaczących zdolności produkcyjnych, gdyż stopień ich wykorzystania był uzależniony od stanu posiadanych zamówień, przede wszystkim eksportowych. Ponadto z powodu zakłóceń w rytmice produkcji zaistniałych w II kwartale 2000 roku, spowodowanych niestabilną polityką współpracy z niektórymi rynkami w zakresie eksportu, nie wykorzystano zdolności produkcyjnej, co wpłynęło na obniżenie produkcji w stosunku do 1999 roku o 675 tys. sztuk asortymentu. W latach 2001-2002 pro- 
dukcja ogółem utrzymywała się na poziomie około 1700 tys. sztuk rocznie, czyli była o $16 \%$ wyższa w stosunku do roku 2000. Największy wzrost w 2001 roku zanotowano w produkcji wyrobów z maszyn kotonowych, bo aż o 20\% w stosunku do roku 2000. Choć w 2002 roku największa produkcja wyrobów nastąpiła również z maszyn kotonowych, to jednak stanowiła ona $91,4 \%$ produkcji z tego rodzaju maszyn w porównaniu z rokiem 2001. Ponad trzykrotnie wzrosła w 2002 roku produkcja wyrobów z maszyn saneczkowych w stosunku do 2001 roku, a o ponad $20 \%$ wyrobów z kooperacji maszyn saneczkowych. Na wzrost produkcji wpłynęła przede wszystkim realizacja zwiększonej ilości przyjętych zamówień eksportowych, od nowo pozyskanych klientów hiszpańskich, w których dominował asortyment damski. Oprócz tego ZPDz „Jarlan” S.A. w roku 2001 rozpoczęły realizację nowego programu przerobowego na rynek angielski, polegającego na skróconym cyklu produkcyjnym, tzn. bez barwienia surowca i wszelkich czynności wykończalniczych. Wpłynęło to na wzrost wydajności w wytwarzaniu asortymentu eksportowego. Produkcję można również podzielić na produkty wytwarzane na potrzeby kraju i na eksport. Zagadnienie to zilustrowano w tabeli 5.

Tabela 5. Produkcja krajowa i eksportowa w ZPDz „Jarlan” S.A. w latach 2000-2002

\begin{tabular}{|l|c|c|c|c|c|c|}
\hline \multirow{2}{*}{ Lata } & \multicolumn{3}{|c|}{ Produkcja wyrobów gotowych } & \multicolumn{3}{c|}{ Wartość sprzedaży wyrobów } \\
& \multicolumn{3}{|c|}{ w sztukach na } & \multicolumn{3}{c|}{ gotowych w tys. złotych na } \\
\cline { 2 - 8 } & kraj & eksport & Razem & kraj & eksport & Razem \\
\hline 2000 & 173652 & 1322428 & 1496080 & 3247 & 35898 & 39145 \\
\hline 2001 & 186045 & 1574872 & 1760917 & 4172 & 34544 & 38716 \\
\hline 2002 & 376626 & 1299849 & 1676475 & 7765 & 33295 & 41060 \\
\hline
\end{tabular}

Źródło: Syntetyczne rachunki wyników wersji porównawczej za lata 2000-2002

Z powyższej analizy oraz przedstawionych danych wynika, iż przedsiębiorstwo większość swoich towarów produkuje dla klientów zagranicznych. Zakład skupił się na produkcji wyrobów, zgodnie z życzeniami i wymogami klientów, z przeznaczeniem na eksport, co świadczy o dużej konkurencyjności produktów pochodzących z ZPDz „Jarlan” S.A. w Jarosławiu. Produkcja na rynek krajowy stanowiła niewielki odsetek ogółu produkcji - 12\% w 2000 roku, 10\% w 2001 roku i 22\% w 2002 roku. Sprzedawanie swoich wyrobów od wielu lat poza granicami naszego kraju daje ZPDz „Jarlan” S.A. przewagę nad innymi firmami w staraniach o klienta po wejściu Polski do Unii Europejskiej, gdyż badane przedsiębiorstwo musiało przystosować się do wymogów europejskich w momencie wkroczenia ze swoimi towarami na te rynki wiele lat temu.

\section{ZBYT PRODUKCJI}

W nowym systemie gospodarowania największym problemem dla wielu przedsiębiorstw nie jest wytworzenie produktu czy uzyskanie półfabrykatów do jego produkcji, lecz znalezienie na dany produkt odbiorcy. Od maja 2004 roku, kiedy Polska stanęła w obliczu zjednoczenia z Unią Europejska, sprzedaż każdego nowego produktu, bez wyrobionej wcześniej marki, może stanowić problem dla większości małych i średnich firm. Kadra za- 
rządzająca ZPDz „Jarlan” S.A., myśląc perspektywicznie o działalności przedsiębiorstwa, w miarę możliwości wprowadza unowocześnienia, tak by mogło sprostać wszystkim wymogom stawianym przez Unię Europejską. Jedno z takich przedsięwzięć podjęto w 2001 roku, wprowadzając innowację technologii barwienia w wyrobie gotowym, ponieważ zastosowana technologia wpływa bezpośrednio na podwyższenie jakości i atrakcyjności produktu.

\section{Sprzedaż na rynku krajowym}

Zakłady Przemysłu Dziewiarskiego „Jarlan” S.A. w Jarosławiu, w minionym systemie gospodarowania, produkowały wyroby bardzo poszukiwane w sklepach. Zarówno jakość, jak i fason proponowanych przez nie produktów decydowały o dużej popularności tej firmy. Przedsiębiorstwo miało zagwarantowane i zakup półfabrykatów i zbyt wytworzonych towarów. Obecnie sytuacja znacznie się zmieniła, dlatego przyjęto nową politykę funkcjonowania. Polega ona na produkcji konkretnych wyrobów dopiero po uzyskaniu zamówienia tak, by ich nie magazynować. Ponadto przemysł dziewiarski, podobnie jak wiele innych, charakteryzuje duże uzależnienie od rynku zbytu, gdyż wyprodukowane towary po pewnym czasie nie znajdują popytu, ponieważ wychodzą z mody, przez co tracą na cenie. W latach 1999-2002 następowały wahania wartości i wielkości sprzedaży produktów na rynek krajowy. W 1999 roku wartość sprzedaży produktów na rynek polski wyniosła 6 029,8 tys. zł za 233,6 tys. sztuk, zaś rok później zaznaczył się spadek o 75,2 tys. sztuk o wartości 2782,6 tys. zł, wynikający przede wszystkim z podjętej przez Zarząd decyzji, o zaniechaniu realizacji zamówień na rynek krajowy na sezon jesienno-zimowy (wartość planowana sprzedaży zaniechanej to około 8,4 mln złotych) oraz ujemnej wartości sprzedaży towarów, spowodowanej zwrotami do magazynu sprzedanych warunkowo wyrobów o wartości $1,9 \mathrm{mln}$ złotych. W celu ograniczenia ryzyka finansowania zapasów wyrobów o niższym niż zakładano popycie rynkowym, kontynuowano produkcję wyłącznie na zamówienia odbiorców. Od 2000 roku zaznacza się systematyczny wzrost produkcji na krajowy rynek, gdyż zaktywizowano sprzedaż kierowaną bezpośrednio do detalu. Wartość sprzedaży produktów w 2001 roku na rynek krajowy wynosiła 4171,7 tys. złotych za 160,1 tys. sztuk, czyli wystąpił niemalże 30\% wzrost sprzedaży w porównaniu z 2000 rokiem (około 1,5 tys. sztuk), wynikający z intensyfikacji sprzedaży. W 2001 roku zaczęto realizować zamówienia indywidualne, a głównie do sieci sprzedaży typu Makro Cash \& Carry oraz produkowano pod marką klienta, np. dla firmy LPP Gdańsk i SIMPLE Warszawa. Do wzrostu sprzedaży przyczyniło się rozwinięcie sieci sklepów detalicznych. Oferta produktów, kierowana na rynek krajowy, zawierała w głównej mierze nadwyżki eksportowe. W 2002 roku wartość sprzedaży produktów na polski rynek wyniosła 7765 tys. złotych i wzrosła o 86\%, w stosunku do 2001 roku. Sprzedano 230,7 tys. sztuk, co równało się wzrostowi o 44\%. Ponadto w 2002 roku zintensyfikowano produkcję na zamówienia indywidualne klientów, z którymi współpracowano w 2001 roku oraz produkowano pod marką nowych klientów: Ordipol Wrocław, Mustang, Big Star, Bon Prix. Do wzrostu sprzedaży przyczyniło się poszerzenie oferty oraz pozyskanie nowych punktów sprzedaży detalicznej. W następnym roku przedsiębiorstwo planowało uzyskać dalszy wzrost wartości sprzedaży na rynku krajowym, przekraczając poziom $8 \mathrm{mln}$ zł, dzięki zaktywizowaniu sprzedaży kierowanej bezpośrednio do detalu oraz zwiększeniu sprzedaży dotychczasowym klientom. 


\section{Kierunki eksportu}

Zakłady Przemysłu Dziewiarskiego „Jarlan” S.A. w Jarosławiu to przedsiębiorstwo, które większość przychodów od wielu lat czerpie ze sprzedaży swoich wyrobów na rynkach zagranicznych. Współpraca z klientami zza granicy ma charakter stały, choć w ostatnich latach zauważalna jest tendencja spadkowa w przychodach ze sprzedaży na eksport.

Tabela 6. Wielkość i wartość sprzedaży eksportowej towarów handlowych przez ZPDz „Jarlan” S.A. w latach 2000-2002

\begin{tabular}{|c|c|c|c|c|c|c|c|c|c|}
\hline \multirow{2}{*}{ KRAJ } & \multicolumn{3}{|c|}{ Ilość w tys. szt. w latach } & \multicolumn{3}{|c|}{ Wartość tys. zł w latach } & \multicolumn{3}{|c|}{$\begin{array}{c}\text { udział wartości } \\
\text { sprzedaży (w \%) }\end{array}$} \\
\hline & 2000 & 2001 & 2002 & 2000 & 2001 & 2001 & 2000 & 2001 & 2002 \\
\hline Włochy & $-*$ & 9,1 & 7,5 & - & 172,6 & 151,0 & - & 0,5 & 0,5 \\
\hline USA & 196,4 & 124,5 & 69,1 & 2550,8 & 2151,4 & 1038,5 & 7,1 & 6,2 & 3,1 \\
\hline Szwecja & 19,1 & 15,3 & 7,7 & 537,3 & 518,9 & 285,3 & 1,5 & 1,5 & 0,9 \\
\hline Portugalia & 124,7 & 57,9 & 27,5 & 2864,6 & 1272,7 & 605,6 & 7,9 & 3,7 & 1,8 \\
\hline Niemcy & 125,7 & 190,2 & 94,0 & 3627,4 & 3996,1 & 2119,6 & 9,1 & 11,6 & 6,4 \\
\hline Hiszpania & 357,7 & 549,6 & 518,5 & 8961,4 & 13917,3 & 14206,3 & 24,8 & 40,3 & 42,6 \\
\hline Francja & 259,1 & 118,8 & 75,9 & 6393,5 & 3188,3 & 2242,0 & 17,7 & 9,2 & 6,7 \\
\hline Dania & - & 1,3 & 0,0 & - & 31,9 & 0,0 & - & 0,1 & 0,0 \\
\hline Belgia & 6,4 & 2,4 & 0,0 & 66,6 & 65,3 & 0,0 & 0,2 & 0,2 & 0,0 \\
\hline Anglia & 348,6 & 475,3 & 521,6 & 11282,8 & 9229,5 & 12205,7 & 31,3 & 26,7 & 36,6 \\
\hline Szwajcaria & 2,8 & - & - & 116,0 & - & - & 0,3 & 0,0 & 0,0 \\
\hline Norwegia & 0,6 & - & - & 27,5 & - & - & 0,1 & 0,0 & 0,0 \\
\hline Słowacja & 0,8 & - & - & 14,6 & - & - & 0,0 & 0,0 & 0,0 \\
\hline Ukraina & - & - & 0,5 & - & - & 15,7 & 0,0 & 0,0 & 0,1 \\
\hline Grecja & - & - & 15,3 & - & - & 424,8 & 0,0 & 0,0 & 1,3 \\
\hline OGÓŁEM & 1441,9 & 1554,4 & 1337,6 & 36082,5 & 34544,0 & 33294,5 & 100 & 100 & 100 \\
\hline
\end{tabular}

* brak danych

Źródło: Opracowanie własne na podstawie Sprawozdania z działalności Spółki za lata 2000-2002 
W 2000 roku ZPDz „Jarlan” S.A. w Jarosławiu eksportowały swoje wyroby do 10 państw Europy i do Stanów Zjednoczonych (tab. 6), sprzedając im prawie 1500 tys. sztuk swoich wyrobów, to jest $91 \%$ ogólnej wartości produkcji. W tym samym roku nastapiły niekorzystne zmiany w realizacji eksportu, gdyż w II kwartale nie udało się podtrzymać współpracy ze strategicznym podwykonawcą z roku 1999, tzn. z ZPDz COTEX, w związku z czym ZPDz „Jarlan” S.A. utraciły część zamówień z rynku hiszpańskiego, niemieckiego i francuskiego. Działania te spowodowały spadek wartości sprzedaży w 2000 roku o około $25 \% \mathrm{w}$ stosunku do roku poprzedniego. W konsekwencji ZPDz COTEX z kooperanta stał się konkurentem zakładów dziewiarskich z Jarosławia. Niestety nie powiódł się również zamiar podpisania umowy o wieloletniej współpracy z firmą COAST VIYELLA w Anglii o dostawy dla sieci Marks \& Spencer. Mimo to przedsiębiorstwo najwięcej swoich wyrobów sprzedało do Anglii, bo aż 348,6 tys. sztuk, co stanowiło ponad 30\% całej sprzedaży eksportowej tego roku. W 2001 roku nastapiły niewielkie zmiany kontrahentów. Zaprzestano współpracy z najsłabszymi klientami z 2000 roku, czyli pochodzącymi z Norwegii, Słowacji i Szwajcarii, ale nawiązano współpracę z klientami z Włoch i Danii. Najwyższe obroty zanotowano z przedsiębiorstwami z Hiszpanii (40\% sprzedaży eksportowej) i Anglii. Z uwagi na bardzo wysokie zdolności produkcyjne, a jednocześnie zahamowanie popytu na niektórych rynkach światowych związane z sytuacją polityczno-gospodarczą po 11 września 2001 roku, dumpingową polityką niektórych krajów azjatyckich, dla utrzymania znaczącej pozycji w zakresie eksportu jak i sprzedaży krajowej w 2002 roku ZPDz „Jarlan” S.A. radykalnie minimalizowały ceny. Przedsiębiorstwo zmuszone było, podobnie zresztą jak w roku 2001, negocjować poziom cen kontraktowych na granicy swojej opłacalności. Działania te spowodowały zmniejszenie rozmiarów wieloletniej współpracy z Firmą Richard Roberts na dostawy do sieci M\&S i powstanie napięć we współpracy z innymi wieloletnimi odbiorcami, związanych z utrzymaniem cen dla zachowania minimalnej rentowności. W 2002 roku największymi kontrahentami, ponownie były przedsiębiorstwa z Anglii i Hiszpanii, do których sprzedano około 1300 tys. sztuk produktów (prawie 80\% eksportu), mających wartość ponad 26 mln złotych. W 2002 roku prócz stałych klientów, z którymi handlowano w latach poprzednich, rozpoczęto współpracę z firmami z Grecji, a także z kontrahentami leżącej niedaleko Jarosławia Ukrainy. Choć w 2002 roku nowi klienci nie tworzyli dużego udziału w całości sprzedaży, to jednak ZPDz „Jarlan” S.A. wiążą z nimi, zwłaszcza z Ukrainą, duże plany na przyszłość, przede wszystkim z powodu bliskiej odległości od firmy oraz z mniejszymi wymaganiami stawianymi jeszcze przez klientów ukraińskich i mniejszym nasyceniem rynku tego kraju przez wyroby, jakie proponuje „Jarlan”.

\section{ANALIZA FINANSOWA}

Stan finansów każdego przedsiębiorstwa daje obraz jego funkcjonowania. Należy zauważyć, iż największy kryzys finansowy przedsiębiorstwo przeżywało w 2000 roku, osiagając straty w wysokości prawie $11 \mathrm{mln}$ zł (ryc. 2). W latach 1999 i 2001 firma osiagała wyniki również ujemne, oscylujące wokół $3 \mathrm{mln}$ zł. W 2002 roku, dzięki profesjonalnemu zarządzaniu w ZPDz „Jarlan” S.A. sytuacja finansowa uległa poprawie. Przedsiębiorstwo osiagnęło zysk w wysokości 1213,1 tys. zł. 


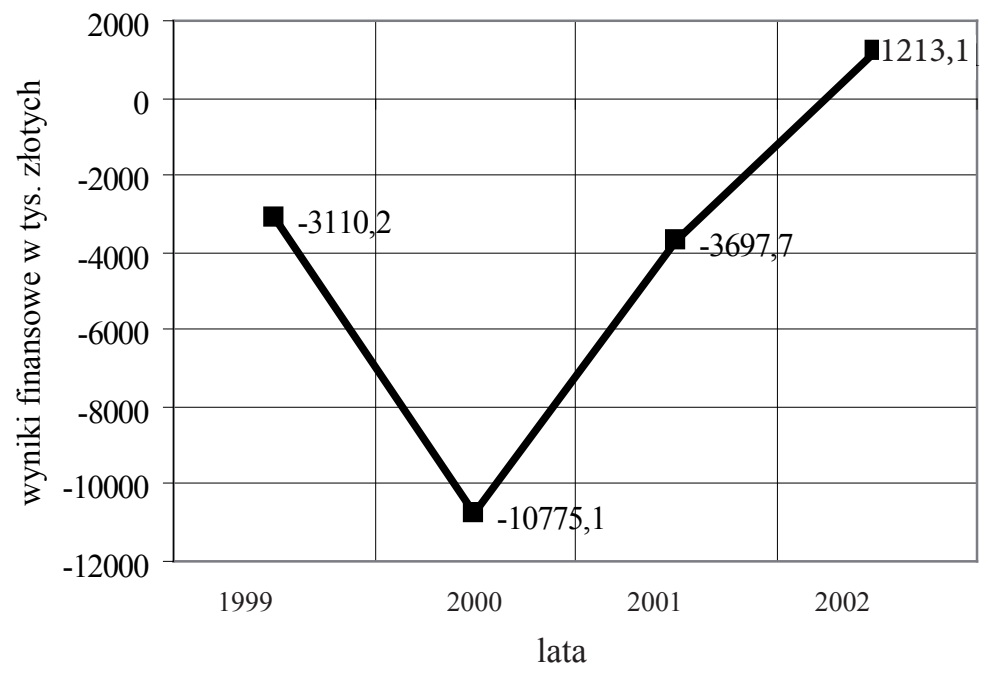

Ryc. 2. Wyniki finansowe ZPDz „Jarlan” S.A. w Jarosławiu osiagnięte w latach 1999-2022

Źródło: Rachunki zysków i strat ZPDz „Jarlan” S.A. za lata 1999-2002

Dla pełnego przedstawienia finansów Zakładu Przemysłu Dziewiarskiego „Jarlan” S.A. należy zaprezentować problematykę płynności finansowej przedsiębiorstwa, czyli zdolności do regulowania należności, która jest pewnego rodzaju odzwierciedleniem sposobu gospodarowania finansami przedsiębiorstwa. Do oceny tego zagadnienia posłużono się średniorocznymi wskaźnikami płynności finansowej za lata 1999-2002 (tab. 7).

Tabela 7. Dynamika średniorocznych wskaźników finansowych ZPDz „Jarlan” S.A. w Jarosławiu za lata 1999-2002 (w \%)

\begin{tabular}{|l|c|c|c|c|c|c|c|}
\hline \multicolumn{1}{|c|}{ Wyszczególnienie } & 1999 & 2000 & 2001 & 2002 & $\begin{array}{c}\text { Dynamika } \\
2000 / 1999\end{array}$ & $\begin{array}{c}\text { Dynamika } \\
2001 / 2000\end{array}$ & $\begin{array}{c}\text { Dynamika } \\
2002 / 2001\end{array}$ \\
\hline $\begin{array}{l}\text { Wskaźnik płynności I stopnia } \\
\text { (wskaźnik bieżącej płynności) }\end{array}$ & 0,90 & 0,69 & 0,48 & 0,71 & 76,7 & 69,6 & 147,9 \\
\hline $\begin{array}{l}\text { Wskaźnik płynności II stopnia } \\
\text { (wskaźnik szybkości) }\end{array}$ & 0,48 & 0,34 & 0,26 & 0,39 & 70,8 & 76,5 & 150,0 \\
\hline $\begin{array}{l}\text { Wskaźnik płynności III stopnia } \\
\text { (środki pieniężne / zobowiązania } \\
\text { krótkoterminowe) }\end{array}$ & 0,01 & 0,01 & 0,01 & 0,01 & 100,0 & 100,0 & 100,0 \\
\hline
\end{tabular}

Źródło: Sprawozdania z działalności Spółki za lata 2000-2002

Biorąc pod uwagę dotychczasowe rezultaty badań należy stwierdzić, iż wysokie straty z działalności finansowych, operacyjnych oraz inwestycyjnych w pierwszych latach analizowanego okresu, negatywnie odbiły się na sytuacji płatniczej Zakładów Przemysłu Dziewiarskiego „Jarlan” S.A. W latach 1999-2001 dynamika średniorocznych wskaźników wykazywała tendencję spadkową wahającą się na poziomie $70 \%$ wskaźników I i II stopnia. 
Istniało zagrożenie wypłacalności przedsiębiorstwa. Jedynym realnym wyjściem z tej sytuacji było przeprowadzenie restrukturyzacji finansowej, która przejawiła się poprawą wskaźników płynności finansowej I i II stopnia o około $50 \%$.

Dokonując oceny działalności Zakładów Przemysłu Dziewiarskiego „Jarlan” S.A. w Jarosławiu, należy przytoczyć wskaźniki efektywności (obrotowości) przedsiębiorstwa za lata 1999-2002 (tab. 8).

Tabela 8. Wskaźniki wysokości środków obrotowych w latach 1999-2002

\begin{tabular}{|c|c|c|c|c|c|c|c|}
\hline \multirow{2}{*}{ Wyszczególnienie } & \multirow{2}{*}{1999} & \multirow{2}{*}{2000} & \multirow{2}{*}{2001} & \multirow{2}{*}{2002} & \multicolumn{3}{|c|}{ Dynamika za lata (w \%) } \\
\hline & & & & & $1999 / 2000$ & $2000 / 2001$ & $2001 / 2002$ \\
\hline $\begin{array}{l}\text { Wskaźnik rotacji zapasów } \\
\text { (w dniach) }\end{array}$ & 58 & 65 & 36 & 41 & 112,1 & 55,4 & 113,9 \\
\hline Cykl należności (w dniach) & 66 & 60 & 44 & 48 & 90,9 & 73,3 & 109,1 \\
\hline $\begin{array}{l}\text { Wskaźnik rotacji aktywów } \\
\text { ogółem }\end{array}$ & 1,22 & 0,99 & 1,34 & 1,41 & 81,1 & 136,4 & 105,2 \\
\hline $\begin{array}{l}\text { Wskaźnik efektywności (koszty } \\
\text { działalności operacyjnej / sprze- } \\
\text { daż netto) }\end{array}$ & 0,94 & 1,13 & 0,99 & 0,95 & 120,2 & 87,6 & 96,0 \\
\hline
\end{tabular}

Źródło: Sprawozdania z działalności Spółki za lata 2000-2002

Systematyczny spadek większości wskaźników obrotowości potwierdza słabą efektywność przedsiębiorstwa. Pozytywna tendencja wskaźnika rotacji aktywów ogółem, z załamaniem w 2000 roku, najlepiej przedstawia przeobrażenia firmy w ostatnich latach. Faktem jest, że finanse ZPDz „Jarlan” S.A. nie są w najlepszym stanie, lecz lata 2001-2002 dają podstawy by przypuszczać, że sytuacja finansowa ulegnie poprawie.

$$
* * *
$$

Zakłady Przemysłu Dziewiarskiego „Jarlan” S.A. w Jarosławiu to przedsiębiorstwo, które swoje produkty sprzedaje przede wszystkim na rynkach zagranicznych. Zdobywanie nowych klientów nie jest sprawą łatwą, ale ze względu na wysoką jakość produkowanych towarów, ich bogatą kolorystykę i wzornictwo należy stwierdzić, iż „Jarlan” ma już pewną pozycję na rynku międzynarodowym. Firma została ponownie zauważona również przez klientów krajowych. Potwierdzeniem tego jest wzrost sprzedaży na rynek Polski oraz zdobycie w ciagu ostatnich lat wielu nagród wyróżniających jarosławskie zakłady dziewiarskie. Oto niektóre z nich:

- laureat Pierwszej Polskiej Edycji Nagrody „Medal Europejski” za kolekcję wyrobów na sezon wiosna-lato 2000. Nagroda przyznawana jest przez Urząd Komitetu Integracji Europejskiej oraz Business Centre Club, 
- nagroda Rynków Zagranicznych „Wybitny Polski Eksporter” w 2000 roku za szczególne osiagnięcia we współpracy gospodarczej z zagranica, a zwłaszcza za wkład w rozwój i promocję polskiej przedsiębiorczości,

- w 2001 roku Nagroda „Junior Eksportu” Przemysłu Lekkiego za bliźniak damski w ramach Poznańskiego Tygodnia Mody przyznana przez Krajową Izbę Gospodarczą,

- w 2004 roku podczas Poznańskiego Tygodnia Mody na Międzynarodowych Targach Poznańskich - tytuł „Mister Junior Eksportu Przemysłu Lekkiego 2004”. Wyróżnienie to zostało przyznane ZPDz „Jarlan” S.A. przez Ministerstwo Gospodarki, Pracy i Polityki Społecznej oraz Krajową Izbę Gospodarczą za kolekcję swetrów damskich i męskich.

Pomimo iż firma przeżywała kryzys finansowy, jak wskazują badania lat 1999-2002, to ostatnie wyniki dają prawo przypuszczać, że finanse firmy ulegają poprawie. ZPDz „Jarlan” S.A. przechodzą w ostatnich latach transformację, co wpływa na wzrost wskaźników wysokości środków obrotowych. Zaplanowanie konkretnych zmian, w zakresie dalszego działania na rzecz podniesienia pozycji konkurencyjnej Zakładów Przemysłu Dziewiarskiego „Jarlan” S.A. w Jarosławiu, może pomóc w ich rozwoju.

\section{Literatura}

Baran A. 1994, „Zakłady Przemysłu Dziewiarskiego „Jarlan” S.A. w Jarosławiu jako przedmiot badań ekonomiczno-społecznych" (praca magisterska), WSP w Krakowie

Delmanowicz D., 2002, Kierunek Ukraina. „Jarlan” zmienił właściciela, „Nowiny” z 21.11.2004

„Gazeta Jarosławska" z 17.03.2004, nr 11 (347)

Kortus B. 1986, Wstęp do geografii przemystu, PWN, Warszawa

Rachwał T. 2001, Problematyka kwestionariusza do badań zmian funkcjonowania przedsiębiorstwa przemystowego $w$ okresie transformacji systemu gospodarowania, [w:] Problemy przemian struktur przestrzennych przemystu, red. Z. Zioło, Prace Komisji Geografii Przemysłu PTG, nr 2, Warszawa-Kraków

Sprawozdania z działalności Zakładów Przemystu Dziewiarskiego „Jarlan” S.A. w Jarosławiu za lata 2000-2002

Winiarski B. 1961, Aktywizacja regionów gospodarczo nierozwiniętych, Warszawa

Witczak J. 2004, Z Solidarności kapitalista, , Polityka”, nr 7(2439)

Zawadzki M.S. 1962, Zaklad przemysłowy jako przedmiot badań ekonomiczno-geograficznych, Warszawa

Zioło Z. 1973, Analiza struktury przestrzennej i form koncentracji przemystu woj. rzeszowskiego w świetle wybranych wskaźników, Folia Geographica, Series Geographica-Oeconomica, vol. VI, Wrocław-Warszawa-Kraków

Zioło Z. red. 1988, Zaktad przemystowy w akademickim ksztatceniu nauczycieli geografii, Materiały i Sprawozdania, COMSN, nr 16, Kraków

Zioło Z. 1994, Zmiany otoczenia przedsiębiorstw przemystowych w nowych warunkach gospodarowania, [w:] Funkcjonowanie przedsiębiorstw przemysłowych $w$ zmieniajacych sie warunkach gospodarowania, red. Z. Zioło, COMSN, Komisja Geografii Przemysłu PTG, Kraków-Warszawa

Zioło Z. 1999, Transformacja struktur subregionalnych Polski południowo-wschodniej w procesie zmian systemu gospodarowania, PAN, Kraków

http://www.polskieprodukty.pl

http://starostwo.jaroslaw.pl./strategia/gospodarka.html

www.jarlan.com.pl 


\section{Changes in the operation of the "Jarlan" Company in Jaroslaw, with special focus on the years 1999-2003}

The Knitting Factory "Jarlan" in Jarosław was established in 1972, when the country's economy was centrally controlled. Initially, "Jarlan" comprised of four smaller plants, but in the process of shifting to market economy some of them were closed as they proved unprofitable. In 1992, the Factory was turned into a sole shareholder company of the Treasury. Subsequently, together with other companies in the clothing - knitting field, "Jarlan" became a part of the "Próchnik" holding, and in 2002 the controlling interest was purchased by Krzysztof Dajczak.

Due to the nature of its production, women prevail among "Jarlan's" employees. In the 1980's, out of 3000 people employed, two-thirds were women. During the transformation period, employment was reduced to 982 people, 199 men and 783 women, which constituted only $28 \%$ of the 1980 employment level.

The year 2000 was a breakthrough for "Jarlan", which resulted from the difficulties that the "Próchnik" holding, to which the Factory belonged, was going through. The number of finished articles dropped significantly and the sales profits were the lowest in the company's entire history -11 million of estimated losses. Measures were undertaken to regain "Jarlan's" financial fluency and its position on the market through winning new customers, especially abroad. As soon as 2002, the profits amounted to $1 \mathrm{mln}$.

Presently, the Knitting Factory "Jarlan" is an international company, selling their turtlenecks, round-neck sweaters, vests, cardigans and tunics mainly to England, Spain, Germany and France. Due to high quality products and varied sets of patterns and colours, the company is extremely competitive, which has been recognized by Polish customers as well. 